\title{
Ekologi Perairan Pulau Tunda Serang Banten: Keadaan Umum Hutan Mangrove
}

\author{
Water Ecology of Tunda Island Serang Banten: General Conditions of the \\ Mangrove Forest
}

\section{Syahrial $^{1 *}$, Dandi Saleky ${ }^{2}$, Agus Putra Abdul Samad ${ }^{3}$, Ilham Antariksa Tasabaramo $^{4}$}

\author{
${ }^{1}$ Program Studi Ilmu Kelautan, Fakultas Pertanian, Universitas Malikussaleh, Aceh, Indonesia \\ ${ }^{2}$ Jurusan Manajemen Sumberdaya Perairan, Fakultas Pertanian, Universitas Musamus, Papua, \\ Indonesia \\ ${ }^{3}$ Program Studi Budidaya Perairan, Fakultas Pertanian, Universitas Samudra, Aceh, Indonesia \\ ${ }^{4}$ Program Studi Ilmu Kelautan, Fakultas Pertanian, Perikanan dan Peternakan, Universitas \\ Sembilanbelas November, Sulawesi Tenggara, Indonesia \\ *Korespondensi: syahrial.marine@unimal.ac.id
}

\begin{abstract}
ABSTRAK
Hutan mangrove kini menghadapi ancaman serius, dimana tekanan antropogenik manusia telah meningkat pesat di wilayah pesisir sekitar kawasan mangrove. Kajian ekologi perairan Pulau Tunda Serang Banten khususnya keadaan umum hutan mangrovenya telah dilakukan pada bulan Januari 2014. Hal ini bertujuan sebagai data dasar dalam mengevaluasi pengelolaan mangrove di Indonesia (khususnya Pulau Tunda Serang Banten) dan kedepannya keberadaan hutan mangrove Indonesia dapat dipertahankan. Data kondisi vegetasi mangrove Pulau Tunda Serang Banten dikumpulkan dengan membuat transek garis dan plot yang ditarik dari titik acuan (tegakan mangrove terluar) dan tegak lurus garis pantai sampai ke daratan. Sementara pengukuran kualitas perairan dilakukan secara in-situ. Hasil penelitian menunjukan bahwa pertumbuhan hutan mangrove Pulau Tunda Serang Banten pada bagian Timur (Stasiun 1) lebih muda dibandingkan bagian Selatan (Stasiun 2). Kemudian kerapatannya juga lebih tinggi di bagian Timur daripada bagian Selatan, namun kondisi hutan mangrove kedua stasiun masih tergolong baik dan sangat padat. Selain itu, kualitas lingkungan vegetasi mangrove Pulau Tunda masih tergolong tinggi, keanekaragaman maupun dominansi hutan mangrovenya tergolong rendah, keseragaman dalam keadaan agak seimbang, pola penyebarannya tergolong beraturan (regular) dan parameter kualitas perairan tidak menjadi penghambat bagi pertumbuhan mangrovenya.
\end{abstract}

Kata kunci: Ekologi perairan, keadaan umum, hutan mangrove, Pulau Tunda

\begin{abstract}
Mangrove forests now face serious threats, where human anthropogenic pressure has increased rapidly in coastal areas around mangrove areas. The ecological study of the waters of Tunda Serang Banten Island, especially the general condition of its mangrove forests, was carried out in January 2014. This was intended as a baseline in evaluating mangrove management in Indonesia (especially Tunda Serang Banten Island) and the presence of Indonesian mangrove forests could be maintained in the future. Data on the condition of the mangrove vegetation of Tunda Serang Banten Island was collected by making line transects and plots drawn from the reference point (outermost mangrove stands) and perpendicular to the coastline to the mainland. While the measurement of
\end{abstract}


water quality is done in-situ. The results showed that the growth of the mangrove forest of Tunda Serang Island in Banten on the East (Station 1) was younger than that in the South (Station 2). Then the density is also higher in the East than in the South, but the condition of the mangrove forests of both stations is still relatively good and very dense. In addition, the environmental quality of Tunda Island's mangrove vegetation is still relatively high, the diversity and dominance of mangrove forests is low, uniformity in a somewhat balanced condition, regular distribution patterns and water quality parameters are not a barrier to the growth of mangroves.

Keywords: Aquatic ecology, general condition, mangrove forest, Tunda Island

\section{PENDAHULUAN}

Hutan mangrove terdistribusi di sepanjang pantai tropis dan subtropis yang terlindungi (Woodroffe dan Grindrod, 1991; Maiti dan Chowdhury, 2013), beradaptasi dengan akar napas, akar tunjang, akar papan, daun pengekskresi garam serta buahnya (propagul) bersifat vivipar (Parvaresh $e t$ al., 2010). Hal ini menjadikan mangrove sebagai tumbuhan yang unik bila dibandingkan dengan tumbuhan lainnya (Chakraborty, 2013). Di dunia, hutan mangrove menghuni lebih dari 152.000 $\mathrm{km}^{2}$, tetapi menempati $<1 \%$ dari zona pesisir dunia (Alongi, 2002; Alongi, 2012), dimana empat puluh tujuh persen (47\%) luas hutan mangrove dunia ditemukan di Indonesia, Brazil, Nigeria, Australia maupun Meksiko (FAO, 2010) dan Indonesia merupakan pemilik kawasan mangrove terluas di Asia Tenggara (31.890 $\left.\mathrm{km}^{2}\right)$ (ITTO, 2012).

Di kawasan pesisir, hutan mangrove memiliki banyak fungsi ataupun manfaat, salah satunya adalah sebagai penjaga keseimbangan ekologi (Jingchun et al., 2010; Du et al., 2013), dimana himpunan vegetasi mangrove dapat menyediakan habitat bagi spesies terestrial, muara maupun laut untuk dimanfaatkan sebagai daerah pembiakan, pertumbuhan, perlindungan dan zona makan (Holguin et al. 2001). Selain itu, hutan mangrove juga melindungi pesisir pantai dari bencana abrasi, badai dan tsunami, mendukung bidang perikanan, menyimpan karbon, menyediakan kayu, meningkatkan kualitas air serta memberikan kesempatan bagi manusia untuk berekreasi (Ewel et al., 1998;
Barbier et al., 2011; Lee et al., 2014), kemudian hutan mangrove juga dapat melindungi wilayah pesisir dari kenaikan permukaan laut (Koch et al., 2009), menjaga dari peristiwa perubahan iklim (Alongi, 2015), memerangkap sedimen (Satheeshkumar dan Khan, 2012; Gillis et al., 2014), mencegah dispersi polutan antropogenik ke ekosistem perairan (Yang et al., 2008), sebagai pertahanan dan daya hidup berbagai sistem sosialekologi pantai (UNEP, 2014), menyerap $\mathrm{CO}_{2}$ (Donato et al., 2011; Pendleton et al., 2012) hingga kaya akan bahan organik (Camilleri, 1992).

Nilai ekonomi ekosistem mangrove diperkirakan mencapai US\$ 14.000 - 16.000/ha/tahun (Barbier et al., 2011), sedangkan nilai ekonomi secara globalnya mencapai US\$ 1.6 miliar/tahun (Polidoro et al., 2010). Namun saat ini tutupan mangrove global telah mengalami penurunan dari waktu ke waktu. Hal ini karena intervensi manusia (Kammerbauer dan Ardon, 1999; Millington et al., 2003; Van Laake dan Sanchez-Azofeifa, 2004; Abdullah dan Nakagoshi, 2007) yang menjadikan ekosistem mangrove sebagai sasaran dalam berbagai kegiatannya (Hartati dan Harudu, 2016) yaitu seperempat (1/4) mangrove dunia hilang melalui konversi budidaya, pertanian dan penggunaan lahan perkotaan (Barbier dan Cox, 2003; Duke et al., 2007; Friess dan Webb 2013), sehingga hutan mangrove dunia mengalami kerusakan atau hilang $1-2 \%$ per tahunnya (Valiela et al., 2001; Alongi, 2002; Primavera, 2006; Duke et al., 2007) dan berdampak terhadap pengurangan keanekaragaman hayati ekosistem mangrove serta penyimpanan 
biomassa karbon (Giri et al., 2008; Siikamaki et al., 2012), kepunahan $16 \%$ spesies mangrove (Polidoro et al., 2010), penurunan sektor perikanan maupun barang dan jasa lainnya (Aboudha dan Kairo, 2001), menyumbang $10 \%$ emisi global (Donato et al., 2011), mengurangi nilai pendapatan tunai maupun penghidupan masyarakat pesisir (FAO, 2007; UNEP, 2014) hingga berdampak terhadap pengurangan kekayaan negaranegara berkembang (Alongi, 2008; Cochard et al., 2008; Barbier, 2014; Spalding et al., 2014). Untuk mencegah timbulnya kerusakan ekosistem mangrove, salah satu langkahnya adalah dengan melakukan pemantauan secara berkala (Purnobasuki, 2011(Syahrial, 2019)). Oleh karena itu, kajian ekologi perairan Pulau Tunda Serang Banten khususnya keadaan umum hutan mangrovenya sangat perlu dilakukan. Hal ini bertujuan untuk data dasar dalam mengevaluasi pengelolaan mangrove di Indonesia (khususnya Pulau Tunda Serang Banten) dan kedepannya keberadaan hutan mangrove Indonesia dapat dipertahankan.

\section{METODE PENELITIAN}

\section{Waktu dan Tempat Penelitian}

Penelitian dilaksanakan pada bulan Januari 2014 di kawasan ekosistem mangrove Pulau Tunda Kabupaten Serang Provinsi Banten. Stasiun 1 berada di bagian Timur pulau, sedangkan Stasiun 2 berada di bagian Selatan pulau (Gambar 1).

\section{Alat dan Bahan Penelitian}

Alat yang digunakan dalam penelitian ini adalah rol meter, buku identifikasi mangrove Noor et al. (2006), data sheet, kamera, GPS Garmin 62 series, alat tulis, thermometer dan hand refractometer, sedangkan bahan yang digunakan adalah aquades untuk mengkalibrasi alat kualitas air.

\section{Pengumpulan Data Kondisi Vegetasi Mangrove Pulau Tunda}

Data kondisi vegetasi mangrove Pulau Tunda Serang Banten dikumpulkan menurut Bengen (2004), dimana vegetasi mangrove dikumpulkan dengan membuat transek garis dan plot yang ditarik dari titik acuan (tegakan mangrove terluar) dan tegak lurus garis pantai sampai ke daratan, kemudian transek garis tersebut dibuat petak-petak contoh (plot) dengan ukuran $10 \times 10 \mathrm{~m}$ (kategori pohon), 5 x 5 $\mathrm{m}$ (kategori anakan) dan $1 \times 1 \mathrm{~m}$ (kategori semai). Setelah dibuat transek garis dan plot, tumbuhan mangrove dideterminasi dan dihitung jumlah individu setiap jenisnya. Selanjutnya diukur lingkar batang pada setinggi dada atau sekitar $1.3 \mathrm{~m}$ dari atas tanah menurut MNLH (2004a).

\section{Pengumpulan Data Kualitas Perairan}

Pengukuran kualitas perairan dilakukan dengan cara in-situ, dimana pengukuran dilakukan dengan cara mengambil contoh air pada masingmasing stasiun pengamatan. Adapun parameter kualitas perairan yang diukur di sekitar kawasan ekosistem mangrove Pulau Tunda adalah suhu dan salinitas.

\section{Analisis Pertumbuhan Mangrove Pulau Tunda}

Analisis pertumbuhan mangrove Pulau Tunda menggunakan data diameter batang yang diperoleh dari pengukuran lingkar batang di lapangan. Adapun prosedur untuk mendapatkan pertumbuhan mangrove Pulau Tunda adalah: (1) menghitung jumlah tegakan mangrove Pulau Tunda di setiap stasiunnya; (2) data diameter batang dikelompokkan ke dalam selang kelas; (3) menentukan banyak kelas menggunakan rumus $1+3.32(\log \mathrm{n})$, dimana $n$ adalah jumlah mangrove Pulau Tunda tiap stasiunnya; (4) menentukan nilai tertinggi dan terendah dari data diameter batang tersebut; (5) data tertinggi diameter batang dikurangi dengan nilai terendah untuk mendapatkan nilai rentang kelasnya; (6) nilai rentang kelas tersebut kemudian dibagi dengan banyaknya kelas untuk memperoleh nilai 
lebar kelas; (7) menjumlahkan data terendah diameter batang (sebagai selang kelas bawah) dengan nilai lebar kelas untuk memperoleh selang kelas atas; (8) menentukan nilai frekuensinya dan (9) mengelompokkan mangrove Pulau Tunda dengan metode Bhattacharya (1967) menggunakan software FISAT II versi 1.2.2.

\section{Analisis Kerapatan dan Kriteria Kerusakan Mangrove Pulau Tunda}

Kerapatan mangrove Pulau Tunda dihitung menggunakan metode penghitungan yang mengacu pada English et al. (1994) dan Bengen (2004), sedangkan kriteria baku penilaian kerusakan mangrovenya mengacu pada MNLH (2004a).

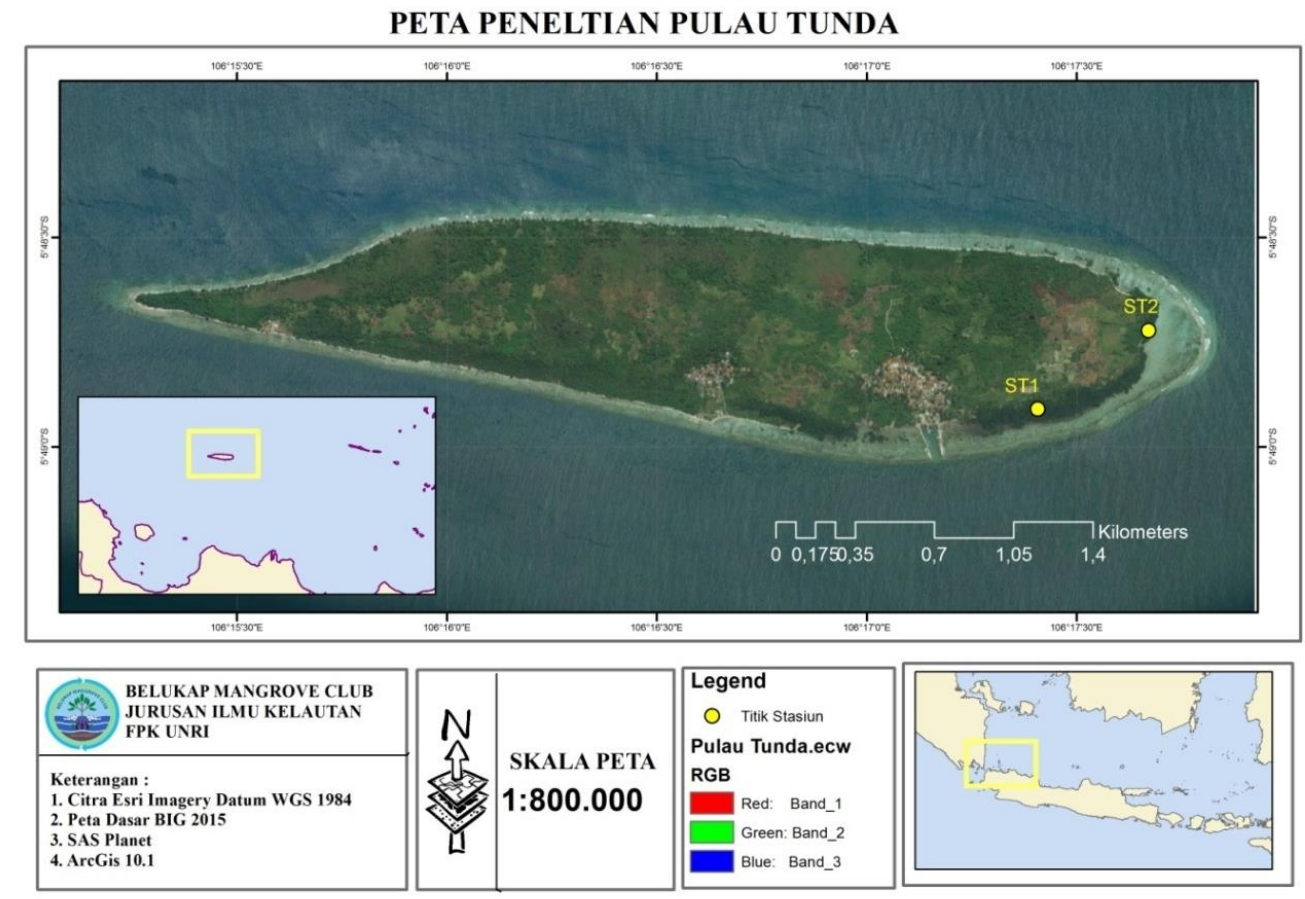

Gambar 1. Peta lokasi penelitian di Pulau Tunda Serang Banten

\section{Analisis Indikator Kualitas Lahan Mangrove Pulau Tunda}

Indikator kualitas lahan mangrove dianalisis menurut Lower Mississipi Valley (1976) dalam Azkia et al. (2013) dan Syahrial (2018) yakni berdasarkan asosiasi spesies, penutupan pohon, penutupan semai, jumlah jenis semai, jumlah hari tergenang dan luasan daerah yang terkena pengaruh pasang surut air laut. Sementara pada penelitian ini, indikator kualitas lahan mangrove yang digunakan hanya berdasarkan penutupan pohon, penutupan semai dan jumlah jenis semai yang ditemukan.
Tabel 1. Indikator kualitas lahan mangrove Lower Mississipi Valley (1976) dalam Azkia et al. (2013) dan Syahrial (2018)

\begin{tabular}{clc}
\hline No & $\begin{array}{c}\text { Indikator Kualitas } \\
\text { Lahan Mangrove }\end{array}$ & Bobot \\
\hline 1 & Penutupan pohon $(\%)$ & 17 \\
2 & Penutupan semai $(\%)$ & 13 \\
3 & Jumlah jenis semai & 12 \\
\hline
\end{tabular}

Indikator-indikator tersebut ditabulasi di dalam grafik Lower Mississipi Valley, dimana indikator penutupan pohon dan semai dihitung berdasarkan banyaknya pohon dan semai yang ditemukan pada suatu komunitas terhadap jumlah keseluruhan kategori mangrove (gabungan tegakan pohon, 
anakan dan semai). Sementara, indikator jumlah jenis semai dihitung berdasarkan banyaknya jenis mangrove kategori semai yang ditemukan.

Adapun persentase indikator penutupan pohon dan penutupan semai dihitung menggunakan rumus:

a. Indikator penutupan pohon

$$
P k=\frac{\sum k}{\sum S k} \times 100 \%
$$

Dimana:

$\mathrm{Pk} \quad$ : Penutupan pohon (\%)

$\sum \mathrm{k}$ : Jumlah pohon dalam suatu komunitas

$\sum$ Sk : Jumlah seluruh jenis kategori mangrove di suatu komunitas

b. Indikator penutupan semai

$$
P s=\frac{\sum s}{\sum S k} \times 100 \%
$$

Dimana:

Ps : Penutupan semai (\%)

$\sum \mathrm{s}$ : Jumlah semai dalam suatu komunitas

$\sum$ Sk : Jumlah seluruh jenis kategori mangrove di suatu komunitas

Untuk menentukan tinggi, sedang atau rendahnya kualitas lingkungan vegetasi mangrove di Pulau Tunda Serang Banten, maka dihitung menggunakan rumus modifikasi dari Lower Mississipi Valley (1976) dalam Azkia et al. (2013) dan Syahrial (2018):

$$
Q e=\frac{\sum(Q i x W)}{\sum W}
$$

Dimana:

Qe : Kualitas lingkungan vegetasi mangrove

Qi : Indeks kualitas lahan mangrove

W : Bobot dari setiap indikator

Kisaran nilai Qe adalah:

Qe $<30 \%$ : Kualitas lingkungan vegetasi mangrove rendah
$30 \% \leq$ Qe $\leq 60 \%$ : Kualitas lingkungan vegetasi mangrove sedang

$60 \% \leq \mathrm{Qe} \leq 100 \%$ : Kualitas lingkungan vegetasi mangrove tinggi

\section{Analisis Indikator Ekologi Komunitas Mangrove Pulau Tunda}

Indikator ekologi komunitas mangrove, dianalisis menggunakan indeks keanekaragaman ShannonWeaver, indeks dominansi Simpson dan indeks keseragaman/kemerataan Shannon-Weaver. Untuk indeks keanekaragaman Shannon-Weaver kriterianya adalah $\mathrm{H}^{\prime} \leq 2.0$ (keanekaragaman rendah), $2.0<\mathrm{H}^{\prime} \leq 3.0$ (keanekaragaman sedang) dan $\mathrm{H}^{\prime} \geq 3.0$ (keanekaragaman tinggi) (Setyobudiandy et al., 2009), kemudian untuk indeks dominansi Simpson kriterianya adalah 0 $<\mathrm{C} \leq 0.5$ (dominansi rendah), $0.5<\mathrm{C} \leq$ 0.75 (dominansi sedang) dan $0.75<\mathrm{C} \leq$ 1 (dominansi tinggi) (Setyobudiandy et al., 2009). Selanjutnya untuk indeks keseragaman/kemerataan ShannonWeaver kriterianya adalah $0<\mathrm{E} \leq 0.5$ (komunitas dalam keadaan tertekan), 0.5 $<\mathrm{E} \leq 0.75$ (komunitas dalam keadaan agak seimbang) dan $0.75<\mathrm{E} \leq 1$ (komunitas dalam keadaan seimbang) (Setyobudiandy et al., 2009).

\section{Analisis Pola Penyebaran Mangrove Pulau Tunda}

Pola penyebaran mangrove Pulau Tunda Serang Banten dianalisis menggunakan Indeks Morisita (I $\delta$ ) (Morisita, 1959; Krebs, 1972; Poole, 1974; Kusmana dan Istomo, 1995; Sakai et al., 1999; Jongjitvimol et al., 2005), dimana kriteria indeksnya adalah $\mathrm{I} \delta=1$ (pola penyebarannya acak), I $\delta<1$ (pola penyebarannya beraturan/regular) dan $\mathrm{I} \delta$ $>1$ (pola penyebarannya mengelompok/clumped).

\section{HASIL DAN PEMBAHASAN}

Pertumbuhan Mangrove Pulau Tunda

Gambar 2 memperlihatkan bahwa
pengelompokkan diameter batang
mangrove Pulau Tunda Serang Banten 
pada kedua stasiun pengamatan hanya terdiri dari satu kelompok, dimana tegakan mangrove Stasiun 1 lebih muda $(6.22 \mathrm{~cm})$ dibandingkan Stasiun $2(6.80$ cm) (Tabel 2).

Selanjutnya Tabel 2 juga memperlihatkan bahwa jumlah populasi mangrove pada Stasiun 1 lebih tinggi (303 ind) dibandingkan dengan Stasiun 2
(261 ind). Hal ini mengindikasikan bahwa tegakan mangrove Pulau Tunda di Stasiun 1 lebih rapat daripada Stasiun 2. Sementara secara keseluruhan, distribusi tegakan mangrove Pulau Tunda didominasi oleh tegakan kategori pohon (rata-rata diameter batangnya besar dari 4 $\mathrm{cm})$.
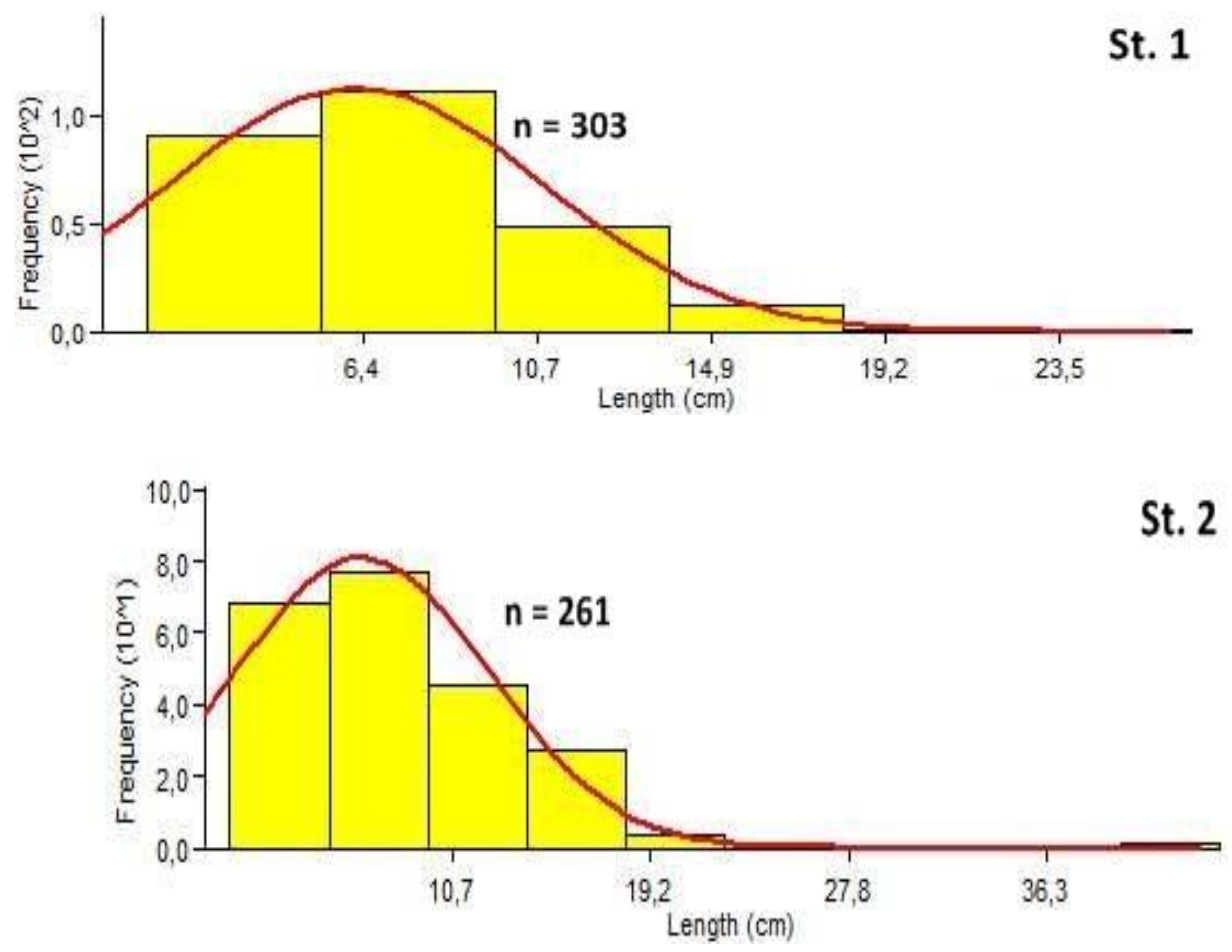

Gambar 2. Pemisahan kelompok diameter batang mangrove Pulau Tunda

Tabel 2. Estimasi pertumbuhan mangrove Pulau Tunda

\begin{tabular}{cccccc}
\hline Stasiun & $\begin{array}{c}\text { Jumlah } \\
\text { Kelompok }\end{array}$ & $\begin{array}{c}\text { Populasi } \\
(\mathbf{n})\end{array}$ & $\begin{array}{c}\text { Diameter Batang } \\
\text { Rata-Rata (cm) }\end{array}$ & $\begin{array}{c}\text { Standar } \\
\text { Deviasi (S.D.) }\end{array}$ & $\begin{array}{c}\text { Index Separasi } \\
(\text { I) }\end{array}$ \\
\hline 1 & 1 & 303 & 6.22 & 4.6 & na \\
2 & 1 & 261 & 6.80 & 5.5 & na \\
\hline
\end{tabular}

\section{Kerapatan dan Kriteria Kerusakan Mangrove Pulau Tunda}

Tabel 3. Kerapatan hutan mangrove di Pulau Tunda Serang Banten

\begin{tabular}{|c|c|c|c|c|c|c|c|}
\hline \multirow[b]{2}{*}{ Stasiun } & \multicolumn{6}{|c|}{ Kerapatan (ind/ha) } & \multirow{2}{*}{ Total } \\
\hline & RA & RS & BG & SC & $\mathbf{R M}$ & $\mathbf{L R}$ & \\
\hline 1 & 1989 & - & 122 & - & 522 & 11 & 2644 \\
\hline 2 & 1244 & 800 & 244 & 11 & - & - & 2299 \\
\hline
\end{tabular}

$\mathrm{RA}=$ Rhizophora apiculata, $\mathrm{RS}=$ Rhizophora stylosa, $\mathrm{BG}=$ Bruguiera gymnorrhiza, $\mathrm{SC}$ $=$ Sonneratia caseolaris, $\mathrm{RM}=$ Rhizophora mucronata, $\mathrm{LR}=$ Lumnitzera racemosa 
Tabel 3 memperlihatkan bahwa kerapatan hutan mangrove di Pulau Tunda Serang Banten, tertingginya di Stasiun I (bagian Timur) dan terendahnya di Stasiun 2 (bagian Selatan). Dibandingkan dengan Keputusan Menteri Negara Lingkungan Hidup No. 201 tahun 2004, hutan mangrove Pulau Tunda Serang Banten masih tergolong baik dan sangat padat $(\geq 1500 \mathrm{ind} / \mathrm{ha}$ ). Polidoro et al. (2010) menyatakan bahwa ancaman utama hutan mangrove adalah degradasi habitat dan konversi lahan untuk akuakultur, pertanian, pengembangan perkotaan/pesisir serta eksploitasi yang berlebihan. Selanjutnya Basyuni et al. (2015) menyatakan bahwa akuakultur dan perkebunan kelapa sawit merupakan penyebab utama hilangnya hutan mangrove di Indonesia, dimana selama 20 tahun terakhir kerusakan hutan mangrove telah mendekati $50-80 \%$ di Jawa, Sulawesi maupun Sumatera (Wolanski et al., 2000).

\section{Indikator Kualitas Lahan Mangrove Pulau Tunda}

Indikator penutupan pohon di Pulau Tunda sebesar $83.96 \%$ dengan nilai indeks kualitas lahan mangrove mencapai 0.96. Bila dibandingkan dengan kriteria baku kerusakan mangrove menurut Keputusan Menteri Negara Lingkungan Hidup No. 201 Tahun 2004, tutupan mangrove di lokasi penelitian masih tergolong baik dan sangat padat $(\geq 75 \%)$. Soraya et al. (2012) menyatakan bahwa penurunan tutupan mangrove dalam skala besar akan mengurangi fungsinya secara fisik, baik itu sebagai penjaga kestabilan garis pantai, pencegah abrasi, pengendali intrusi, penangkap lumpur/sedimen, pengendali banjir maupun pemelihara kualitas air.

Selain itu, hasil pengukuran di lapangan juga memperlihatkan bahwa indikator penutupan semai di Pulau Tunda Serang Banten sebesar 08.11\% dengan nilai indeks kualitas lahan mangrovenya mencapai 0.25 (Gambar 4), sedangkan indikator jumlah jenis semai mencapai 0.95 dengan jumlah semai yang ditemukan sebanyak enam (6) spesies (Gambar 5). Menurut Sillanpaa et al. (2017) keberhasilan regenerasi mangrove merupakan komponen kunci terhadap pemanenan keberlanjutan produktivitas hutan, hasil, keanekaragaman hayati maupun layanan ekosistem untuk pengelolaan di masa yang akan dating. Mukhlisi dan Gunawan (2016) menyatakan bahwa regenerasi semai pada hutan mangrove merupakan salah satu bagian penting dalam proses suksesi sekunder, kemudian tumbuhnya jenis-jenis semai alami mangrove memiliki hubungan erat dengan ketersediaan pohon induknya.

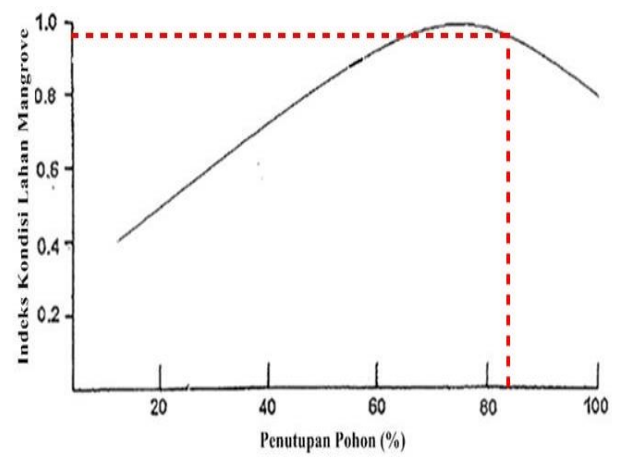

Gambar 3. Hubungan penutupan pohon terhadap indeks kualitas lahan mangrove Pulau Tunda Serang Banten

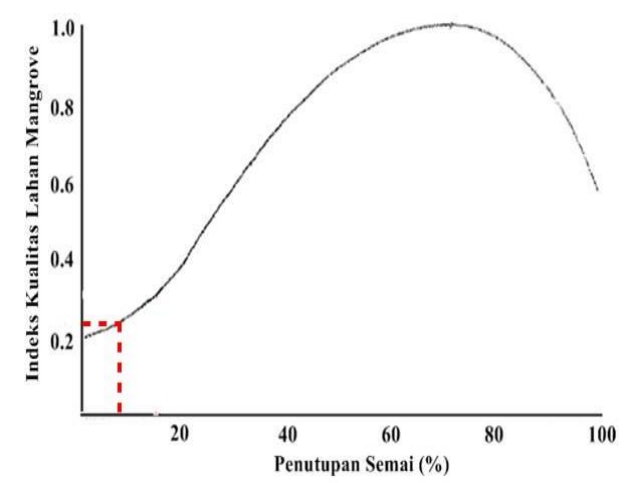

Gambar 4. Hubungan penutupan semai terhadap indeks kualitas lahan mangrove Pulau Tunda Serang Banten 
Tabel 4. Perhitungan kualitas lingkungan vegetasi mangrove Pulau Tunda Serang Banten

\begin{tabular}{lcccc}
\hline \multicolumn{1}{c}{ Indikator } & Nilai Indikator & Qi & W & Qi x W \\
\hline Penutupan pohon & 83.96 & 0.96 & 17 & 16.32 \\
Penutupan semai & 08.11 & 0.25 & 13 & 03.25 \\
Jumlah jenis semai & 06.00 & 0.95 & 12 & 11.40 \\
Total & & $\mathbf{4 2}$ & $\mathbf{3 0 . 9 7}$ \\
Kualitas lingkungan vegetasi mangrove (Qe) & & & $\mathbf{7 3 . 7 4}$ \\
\hline
\end{tabular}

Tabel 5. Keanekaragaman, dominansi dan keseragaman mangrove Pulau Tunda Serang

\begin{tabular}{ccccc}
\multicolumn{2}{c}{ Banten } & & & \\
\hline Stasiun & Jumlah Spesies & H' & C & E \\
\hline 1 & 207 & 1.39 & 0.43 & 0.70 \\
2 & 238 & 1.01 & 0.61 & 0.50 \\
\hline \multicolumn{2}{c}{ Rata-Rata } & $\mathbf{1 . 2 0}$ & $\mathbf{0 . 5 2}$ & $\mathbf{0 . 6 0}$
\end{tabular}

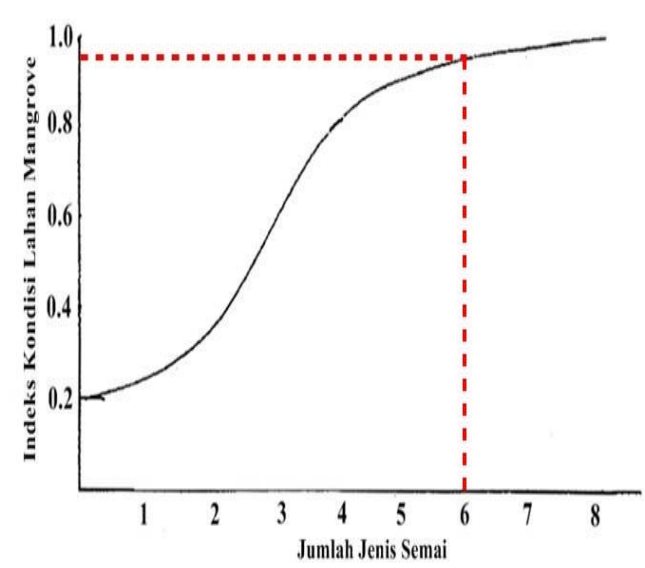

Gambar 5. Hubungan jumlah jenis semai terhadap indeks kualitas lahan mangrove Pulau Tunda Serang Banten

Tabel 4 menunjukkan bahwa kualitas lingkungan vegetasi mangrove di Pulau Tunda Serang Banten sekitar $73.74 \%$ dan telah mengalami perubahan sebesar $26.26 \%$ dari kondisi idealnya. Valiela et al. (2001) menyatakan bahwa hutan mangrove memiliki relevansi ekologi yang tinggi dan banyak kota-kota berdekatan dengannya. Menurut Green $e t$ al. (1996) tingkat pertumbuhan penduduk yang tinggal di daerah pesisir diperkirakan mencapai $60 \%$. Selanjutnya UNEP (2014) menambahkan bahwa lebih dari 100 juta orang tinggal dalam jarak $10 \mathrm{~km}$ dari kawasan mangrove dan jumlah ini diperkirakan akan meningkat sekitar 120 juta orang pada tahun 2015 . Friess dan Webb (2013) menyatakan bahwa tekanan yang paling umum dialami oleh ekosistem mangrove adalah konversi penggunaan lahan budidaya, pertanian dan pembangunan perkotaan, sehingga sekitar 35\% hutan mangrove hilang di akhir abad ke-20 (Valiela et al., 2001) dan mangrove yang tersisa bisa menjadi fungsional paling berharga pada abad ke-21 (Duke et al., 2007; Polidoro et al., 2010).

Tabel 5 juga memperlihatkan bahwa rata-rata nilai dominansi mangrove di Pulau Tunda Serang Banten adalah 0.52, sehingga komunitasnya dikategorikan rendah. Syahrial (2018) menyatakan bahwa rendahnya nilai dominansi mengindikasikan bahwa komunitas mangrovenya berkompetisi secara bersama-sama dalam memanfaatkan ruang, cahaya matahari, tidak terjadinya pemusatan oleh suatu jenis, daya adaptasinya luas dan komunitasnya tersebar merata.

Menurut Munthe et al. (2012) indeks dominansi digunakan untuk mengetahui sejauh mana suatu spesies mendominansi spesies lainnya. Selain itu, Tabel 5 juga memperlihatkan bahwa ratarata nilai keseragaman mangrovenya adalah 0.60 yang mengambarkan komunitasnya dalam keadaan agak seimbang. Menurut Supriadi et al. (2015) 
rendahnya indeks keseragaman suatu komunitas mengindikasikan bahwa kondisi lingkungannya semakin tidak stabil (tidak seimbang) dan menunjukkan komunitasnya dalam keadaan tertekan.

\section{Indikator Ekologi Komunitas Mangrove Pulau Tunda}

Tabel 5 memperlihatkan bahwa rata-rata nilai keanekaragaman mangrove di Pulau Tunda Serang Banten adalah 1.20. Hal ini mengindikasikan bahwa keanekaragaman hutan mangrovenya tergolong rendah dan kondisi vegetasinya juga kurang baik, dimana sebagian besar jenis mangrovenya tidak mampu menyesuaikan diri dengan lingkungan sekitarnya dan diduga mengalami gangguan. Penelitian yang dilakukan oleh Syahrial (2018) di hutan mangrove Utara Indonesia (Pulau Miangas) juga menunjukkan indeks keanekaragaman yang hampir sama yakni 1.35 dan tergolong rendah. Menurut Latuconsina et al. (2012) indeks keanekaragaman merupakan nilai yang dapat menunjukkan keseimbangan keanekaragaman dalam suatu pembagian jumlah individu tiap spesiesnya. Selanjutnya Insafitri (2010) menyatakan bahwa keanekaragaman biota dalam suatu perairan sangat tergantung pada banyaknya spesies di suatu komunitas tersebut, sedangkan Brower et al. (1990) menyatakan bahwa keanekaragaman jenis merupakan suatu ekspresi dari struktur komunitas, dimana suatu komunitas dikatakan memiliki keanekaragaman jenis yang tinggi, apabila proporsi antar jenis secara keseluruhannya sama banyak. Sementara Odum (1996) menyatakan bahwa nilai indeks keanekaragaman dapat digunakan untuk mengetahui pengaruh gangguan terhadap lingkungan atau untuk mengetahui tahapan suksesi dan kestabilan dari komunitas tumbuhan pada suatu lokasi.

\section{Pola Penyebaran Mangrove Pulau Tunda}

Tabel 6 memperlihatkan bahwa secara keseluruhan pola penyebaran mangrove di Pulau Tunda Serang Banten tergolong beraturan (regular). Hal ini mengindikasikan bahwa adanya interaksi negatif antara individu, baik itu persaingan dalam memperebutkan ruang, unsur hara maupun cahaya matahari. Pemberton dan Frey (1984) serta Husein et al. (2017) menyatakan bahwa pola penyebaran yang seragam juga dapat disebabkan oleh interaksi negatif antara individu-individu, misalnya kompetisi terhadap ketersediaan makanan. Selanjutnya Smith et al. (2003) menyatakan bahwa stabilitas mangrove sangat dipengaruhi oleh salinitas, jenis dan kimia tanah, kandungan gizi maupun dinamikanya, toleransi fisiologis, predasi, kompetisi serta campur tangan manusia. Selain itu, ekosistem mangrove juga sangat dipengaruhi oleh pengendapan / sedimentasi, ketinggian rata-rata permukaan laut dan pencemaran perairan (Purnobasuki, 2011).

\section{Karakteristik Parameter Kualitas Air}

Hasil pengukuran paramater suhu perairan di kedua stasiun berkisar antara $27.67-28.30^{\circ} \mathrm{C}$, sedangkan salinitasnya berkisar antara 30.67 - 31.67\%o (Tabel 7). Bervariasinya suhu dan salinitas perairan di lokasi penelitian tidak menyebabkan sebagai faktor pembatas bagi kelangsungan hidup mangrove Pulau Tunda Serang Banten. Menurut Ghosh (2011) hutan mangrove merupakan ekosistem yang sangat rentan terhadap pengaruh lingkungan, salah satunya adalah perubahan suhu (Alongi, 2008). 
Tabel 6. Pola penyebaran hutan mangrove Pulau Tunda Serang Banten

\begin{tabular}{clcc}
\hline Stasiun & $\begin{array}{c}\text { Jenis Mangrove } \\
\text { Pulau Tunda }\end{array}$ & Indeks Morisita $(\mathbf{I} \boldsymbol{\delta})$ & $\begin{array}{c}\text { Pola } \\
\text { Penyebaran }\end{array}$ \\
\hline \multirow{4}{*}{1} & Rhizophora apiculata & 0.00 & Beraturan (Regular) \\
& Bruguiera gymorrhiza & 0.02 & Beraturan (Regular) \\
& Rhizophora stylosa & 0.01 & Beraturan (Regular) \\
& Rhizophora apiculata & 0.00 & Beraturan (Regular) \\
2 & Rhizophora mucronata & 0.01 & Beraturan (Regular) \\
& Bruguiera gymorrhiza & 0.10 & Beraturan (Regular) \\
& Lumnitzera racemosa & 0.00 & Beraturan (Regular) \\
\hline
\end{tabular}

Tabel 7. Karakteristik parameter kualitas air di Pulau Tunda Serang Banten

\begin{tabular}{ccc}
\hline \multirow{2}{*}{ Stasiun } & \multicolumn{2}{c}{ Kualitas Air } \\
\cline { 2 - 3 } & Suhu $\left({ }^{\circ} \mathbf{C}\right)$ & Salinitas (\%o) \\
\hline 1 & $27.67 \pm 0.58$ & $30.67 \pm 0.58$ \\
2 & $28.30 \pm 0.58$ & $31.67 \pm 0.58$ \\
\hline Baku mutu MNLH (2004b) & $28-32$ & s/d 34 \\
\hline
\end{tabular}

Suhu rata-rata memberikan penjelasan secara korelatif terhadap penyebaran mangrove, dimana persyaratan pengukuran suhu minimum memberikan pendekatan mekanistik yang lebih baik untuk mengukur ambang batasnya (Osland et al., 2013). Selain itu, Nguyen et al. (2015) menyatakan bahwa salinitas merupakan salah satu ciri lingkungan yang dapat mendefinisikan habitat mangrove apakah berkisar antara air tawar ataupun hypersaline. Berdasarkan Keputusan Menteri Negara Lingkungan Hidup Nomor 51 Tahun 2004 Tentang Baku Mutu Air Laut untuk Biota Laut, secara keseluruhan kisaran parameter kualitas perairan di Pulau Tunda Serang Banten masih dalam batas toleransi bagi kehidupan mangrove.

\section{KESIMPULAN}

Pertumbuhan hutan mangrove Pulau Tunda Serang Banten didominasi oleh tegakan kategori pohon, dimana tegakan mangrove Stasiun 1 lebih muda dibandingkan Stasiun 2, kemudian kerapatan mangrove lebih tinggi di Stasiun 1 dibandingkan Stasiun 2 dan kondisi hutan mangrove kedua stasiunnya masih tergolong baik serta sangat padat. Selanjutnya kualitas lingkungan vegetasi mangrove masih tergolong tinggi, keanekaragaman maupun dominansi hutan mangrovenya tergolong rendah, keseragaman dalam keadaan agak seimbang, pola penyebarannya tergolong beraturan (regular) dan parameter suhu maupun salinitas perairan tidak menyebabkan penghambat bagi kelangsungan hidup mangrovenya.

\section{UCAPAN TERIMA KASIH}

Ucapan terimakasih disampaikan kepada mas Nana Oyod dan teman-teman yang telah membantu saat pengambilan sampel di lapangan dan ucapkan terimakasih juga disampaikan kepada Bapak Kepala Desa yang telah memberikan izin sehingga terlaksananya penelitian ini.

\section{DAFTAR PUSTAKA}

Abdullah, S. A., Nakagoshi, N., 2007. Forest fragmentation and its correlation to human land use change in the state of Selangor, Peninsular Malaysia. Forest Ecology and Management. 241(13): $39-48$.

Aboudha, P. A. W., Kairo, J. G., 2001. Human-induced stresses on mangrove swamps along the Kenyan coast. Hydrobiologia. 458(1-3): 255 - 265.

Alongi, D. M., 2002. Present state and 
future of the world's mangrove forests. Environmental Conservation. 29(3): 331 - 349.

Alongi, D. M., 2008. Mangrove forests: Resilience, protection from tsunamis, and responses to global climate change. Estuarine, Coastal and Shelf Science. 7(6): $1-13$.

Alongi, D. M., 2012. Carbon sequestration in mangrove forests. Carbon Management. 3(3): 313 322.

Alongi, D. M., 2015. The impact of climate change on mangrove forests. Current Climate Change Reports. 1(1): $30-39$.

Azkia, F. A., Anggoro, S., Taruna, T., 2013. Kajian kualitas lingkungan mangrove di Dukuh Tambaksari Kecamatan Sayung, Kabupaten Demak. Dalam: Prosiding Seminar Nasional Pengelolaan Sumberdaya Alam dan Lingkungan. 10 September 2013. Semarang, Indonesia.

Barbier, E. B., 2014. A global strategy for protecting vulnerable coastal populations. Science. 345(6202): $1250-1251$.

Barbier, E. B., Cox, M., 2003. Does economic development lead to mangrove loss? A cross-country analysis. Contemporary Economic Policy. 21(4): 418 - 432.

Barbier, E. B., Hacker, S. D., Kennedy, C., Koch, E. W., Stier, A. C., Silliman, B. R., 2011. The value of estuarine and coastal ecosystem services. Ecological Monographs. 81(2): 169 - 193.

Basyuni, M., Putri, L. A. P., Murni, M. B., 2015. Implication of land-use and land-cover change into carbon dioxide emissions in Karang Gading and Langkat Timur wildlife reserve, North Sumatra, Indonesia. Manajemen Hutan Tropika. 21(1): $25-35$

Bengen, D. G., 2004. Pedoman Teknis Pengenalan dan Pengelolaan Ekosistem Mangrove. Bogor (ID): Pusat Kajian Sumberdaya Pesisir dan Lautan, IPB.
Bhattacharya, C. G., 1967. A simple method of resolution of a distribution into gaussian components. Biometrics. 23(1): 115 -135 .

Brower, J. E., Zar, J. H., von Ende, C. N., 1990. Field and Laboratory Methods for General Ecology Third Edition. Dubuque, Iowa. $237 \mathrm{p}$.

Camilleri, J. C., 1992. Leaf-litter processing by invertebrates in a mangrove forest in Queensland. Marine Biology. 114(1): 139 - 145.

Chakraborty, S. K., 2013. Interactions of environmental variables determining the biodiversity of coastal-mangrove ecosystem of West Bengal, India. The Ecoscan. 3(Special): $251-265$.

Cochard, R., Ranamukhaarachchi, S. L., Shivakoti, G. P., Shipin, O. V., Edwards, P. J., Seeland, K. T., 2008. The 2004 tsunami in Aceh and Southern Thailand: A review on coastal ecosystems, wave hazards and vulnerability. Perspectives in Plant Ecology, Evolution and Systematics. 10(1): 3 $-40$.

Donato, D. C., Kauffman, J. B., Murdiyarso, D., Kurnianto, S., Stidham, M., Kanninen, M., 2011. Mangroves among the most carbonrich forests in the tropics. Nature Geoscience. 4: 293 - 297.

Du, J., Yan, C., Li, Z., 2013. Formation of iron plaque on mangrove Kandalar obovata (S.L.) root surfaces and its role in cadmium uptake and translocation. Marine Pollution Bulletin. 74(1): 105 109.

Duke, N. C., Meynecke, J. O., Dittmann, S., Ellison, A. M., Anger, K., Berger, U., Cannicci, S., Diele, K., Ewel, K. C., Field, C. D., Koedam, N., Lee, S. Y., Marchand, C., Nordhaus, I., Dahdouh-Guebas, F., 2007. A world without mangroves?. Science. 317(5834): $41-42$.

English, S., Wilkinson, C., Baker, V., 
1994. Survey Manual For Tropical Marine Resources. ASEANAustralia Marine Science Project: Living Coastal Resources, Australian Institute of Marine Science. Townsvile (AUS).

Ewel, K. C., Twilley, R. R., Ong, J. E., 1998. Different kinds of mangrove forests provide different goods and services. Global Ecology and Biogeography Letters. 7(1): 83 94.

[FAO] Food and Agriculture Organization., 2007. The World's Mangroves 1980 - 2005: A Thematic Study Prepared in The Frameworkof The Global Forest Resources Assessment 2005. Roma, Itali. 89p.

[FAO] Food and Agriculture Organization., 2010. Global Forest Resources Assessment 2010: Main Report: FAO Forestry Paper 163. Roma, Itali. 378p.

Friess, D. A., Webb, E. L., 2013. Variability in mangrove change estimates and implications for the assessment of ecosystem service provision. Global Ecol Biogeogr. 23(7): $715-725$.

Ghosh, D., 2011. Mangroves: The most fragile forest ecosystem. Resonance. 16(1): $47-60$.

Gillis, L. G., Bouma, T. J., Jones, C. G., van Katwijk, M. M., Nagelkerken, I., Jeuken, C. J. L., Herman, P. M. J., Ziegler, A. D., 2014. Potential for landscape-scale positive interactions among tropical marine ecosystems. Marine Ecology Progress Series. 503: 289 - 303.

Giri, C., Zhu, Z., Tieszen, L. L., Singh, A., Gillette, S., Kelmelis, J. A., 2008. Mangrove forest distributions and dynamics (1975-2005) of the tsunami-affected region of Asia. Biogeography. 35(3): 519 - 528.

Green, E. P., Mumby, P. J., Edwards, A. J., Clark, C. D., 1996. A review of remote sensing for the assessment and management of tropical coastal resources. Coastal Management. 24: $1-40$.
Hartati, Harudu, L., 2016. Identifikasi jenis-jenis kerusakan ekosistem hutan mangrove akibat aktivitas manusia di Kelurahan Lowulowu Kecamatan Lea-Lea Kota Baubau. Penelitian Pendidikan Geografi. 1(1): $30-45$.

Holguin, G., Vazquez, P., Bashan, Y., 2001. The role of sediment microorganisms in the productivity, conservation, and rehabilitation of mangrove ecosystems: An overview. Biology and Fertility of Soils. 33(4): 265 - 278.

Husein, S., Bahtiar, Oetama, D., 2017. Studi kepadatan dan distribusi Keong Bakau (Telescopium telescopium) di perairan mangrove Kecamatan Kaledupa Kabupaten Wakatobi. Manajemen Sumber Daya Perairan. 2(3): 235 - 242.

Insafitri., 2010. Keanekaragaman, keseragaman dan dominansi bivalvia di area buangan lumpur lapindo Muara Sungai Porong. Kelautan. 3(1): 54 - 59.

[ITTO] International Tropical Timber Organization., 2012. ITTO Tropical Forest Update : A Newsletter from The International Tropical Timber Organization to Promote The Conservation and Sustainable Development of Tropical Forest. Yokohama, Jepang. 24p.

Jingchun, L., Chongling, Y., Spencer, K. L., Ruifeng, Z., Haoliang, L., 2010. The distribution of acid-volatile sulfide and simultaneously extracted metals in sediments from a mangrove forest and adjacent mudflat in Zhangjiang Estuary, China. Marine Pollution Bulletin. 60: $1209-1216$.

Jongjitvimol, T., Boontawon, K., Wattanachaiyingcharoen, W., Deowanish, S., 2005. Nest dispersion of a stingless bee species, Trigona collina Smith, 1857 (Apidae, Meliponinae) in a mixed deciduous forest in Thailand. The Natural History Journal of Chulalongkorn University. 5(2): 69 
-71 .

Kammerbauer, J., Ardon, C., 1999. Land use dynamics and landscape change pattern in a typical watershed in the hillside region of central Honduras. Agriculture, Ecosystems and Environment. 75(1-2): 93 - 100.

Koch, E. W., Barbier, E. B., Silliman, B. R., Reed, D. J., Perillo, G. M. E., Hacker, S. D., Granek, E. F., Primavera, J. H., Muthiga, N., Polasky, S., Halpern, B. S., Kennedy, C. J., Kappel, C. V., Wolanski, E., 2009. Non-linearity in ecosystem services: Temporal and spatial variability in coastal protection. Frontiers in Ecology and The Environment. 7(1): 29 37.

Krebs, C. J., 1972. Ecology: The Experimental Analysis of Distribution and Abundance. New York: Harper \& Row.

Kusmana, C., Istomo., 1995. Ekologi Hutan. Laboratorium Kehutanan Fakultas Kehutanan. Institut Pertanian Bogor. Bogor.

Latuconsina, H., Nessa, M. N., Rappe, R. A., 2012. Komposisi spesies dan struktur komunitas ikan padang lamun di perairan Tanjung Tiram Teluk Ambon Dalam. Ilmu dan Teknologi Kelautan Tropis. 4(1): 35 $-46$.

Lee, S. Y., Primavera, J. H., DahdouhGuebas, F., McKee, K., Bosire, J. O., Cannicci, S., Diele, K., Fromard, F., Koedam, N., Marchand, C., Mendelssohn, I., Mukherjee, N., Record, S., 2014. Ecological role and services of tropical mangrove ecosystems: A reassessment. Global Ecology and Biogeography. 23(7): 726 - 743.

Maiti, S. K., Chowdhury, A., 2013. Effects of anthropogenic pollution on mangrove biodiversity: A review. Environmental Protection. 4(12): $1428-1434$.

Millington, A. C., Velez-Liendo, X. M., Bradley, A. V., 2003. Scale dependence in multitemporal mapping of forest fragmentation in
Bolivia: Implications for explaining temporal trends in landscape ecology and applications to biodiversity conservation. ISPRS Journal of Photogrammetry and Remote Sensing. 57(4): 289 - 299.

[MNLH] Menteri Negara Lingkungan Hidup Republik Indonesia., 2004a.

Keputusan Menteri Negara Lingkungan Hidup Nomor : 201 Tahun 2004 Tentang Kriteria Baku dan Pedoman Penentuan Kerusakan Mangrove. Jakarta, Indonesia.

[MNLH] Menteri Negara Lingkungan Hidup Republik Indonesia., 2004b. Keputusan Menteri Negara Lingkungan Hidup No.51 Tahun 2004 Tentang Baku Mutu Air Laut. Jakarta, Indonesia.

Morisita, M., 1959. Measuring of dispersion of individuals and analysis of the distributional patterns. Memories of the Faculty of Science Kyushu University Series E (Biology). 2(4): 215 - 235 .

Mukhlisi, Gunawan, W., 2016. Regenerasi alami semai mangrove di areal terdegradasi Taman Nasional Kutai. Penelitian Kehutanan Wallacea. 5(2): 113 122.

Munthe, Y. V., Aryawati, R., Isnaini., 2012. Struktur komunitas dan sebaran fitoplankton di perairan Sungsang Sumatera Selatan. Maspari. 4(1): 122 - 130.

Nguyen, H. T., Stanton, D. E., Schmitz, N., Farquhar, G. D., Ball, M. C., 2015. Growth responses of the mangrove Avicennia marina to salinity: Development and function of shoot hydraulic systems require saline conditions. Annals of Botany. 115(3): $397-407$.

Noor, Y. R., Khazali, M., Suryadiputra, I. N. N., 2006. Panduan Pengenalan Mangrove Di Indonesia. Bogor, Indonesia.

Odum, E. P., 1996. Dasar-Dasar Ekologi. Gadjah Mada University Press. Yogyakarta, Indonesia.

Osland, M. J., Enwright, N., Day, R. H., 
Doyle, T. W., 2013. Winter climate change and coastal wetland foundation species: Salt marshes vs. mangrove forests in the Southeastern United States. Global Change Biology. 19(5): 1482 1494.

Parvaresh, H., Abedi, Z., Farshchi, P., Karami, M., Khorasani, N., Karbassi, A., 2010. Bioavailability and concentration of heavy metals in the sediments and leaves of grey mangrove, Avicennia marina (Forsk.) Vierh, in Sirik Azini Creek, Iran. Biological Trace Element Research. 143(2): 1121 - 1130.

Pemberton, S. G., Frey, R. W., 1984. Quantitative methods in ichnology: Spatial distribution among population. Lethaia. 17: 33 - 49.

Pendleton, L., Donato, D. C., Murray, B. C., Crooks, S., Jenkins, W. A., Sifleet, S., Craft, C., Fourqurean, J. W., Kauffman, J. B., Marba, N., Megonigal, P., Pidgeon, E., Herr, D., Gordon, D., Baldera, A., 2012. Estimating global "blue carbon" emissions from conversion and degradation of vegetated coastal ecosystems. Plos One. 7(9): 1 -7.

Polidoro, B. A., Carpenter, K. E., Collins, L., Duke, N. C., Ellison, A. M., Ellison, J. C., Farnsworth, E. J., Fernando, E. S., Kathiresan, K., Koedam, N. E., Livingstone, S. R., Miyagi, T., Moore, G. E., Nam, V. N., Ong, J. E., Primavera, J. H., Salmo, S. G., Sanciangco, J. C., Sukardjo, S., Wang, Y., Yong, J. W. H., 2010. The loss of species: Mangrove extinction risk and geographic areas of global concern. Plos One. 5(4): 1 - 10.

Poole, R. W., 1974. An Introduction to Quantitative Ecology. New York: McGraw-Hill.

Primavera, J. H., 2006. Overcoming the impacts of aquaculture on the coastal zone. Ocean and Coastal Management. 49: 531 - 545.

Purnobasuki, H., 2011. Ancaman terhadap hutan mangrove di Indonesia dan langkah strategis pencegahannya. Bulletin PSL Universitas Surabaya. 25: 3-6.

Sakai, S., Momose, K., Yumoto, T., Nagamitsu, T., Nagamasu, H., Hamid, A. A., Nakashizuka, T., 1999. Plant reproductive phenology over four years including an episode of general flowering in a lowland dipterocarp forest, Sarawak, Malaysia. American Journal of Botany. 86(10): 1414 1436.

Satheeshkumar, P., Khan, A. B., 2012. Identification of mangrove water quality by multivariate statistical analysis methods in Pondicherry coast, India. Environmental Monitoring and Assessment. 184(6): 3761 - 3774.

Setyobudiandi, I., Sulistiono, Yulianda, F., Kusmana, C., Hariyadi, S., Damar, A., Sembiring, A., Bahtiar., 2009. Sampling dan Analisis Data Perikanan dan Kelautan: Terapan Metode Pengambilan Contoh di Wilayah Pesisir dan Laut. Fakultas Perikanan dan Ilmu Kelautan, Institur Pertanian Bogor. Bogor, Indonesia.

Siikamaki, J., Sanchirico, J. N., Jardine, S. L., 2012. Global economic potential for reducing carbon dioxide emissions from mangrove loss. Proceedings of the National Academy of Sciences.109(36): $14369-14374$

Sillanpaa, M., Vantellingen, J., Friess, D. A., 2017. Vegetation regeneration in a sustainably harvested mangrove forest in West Papua, Indonesia. Forest Ecology and Management. 390: 137 - 146.

Smith, K. A., Ball, T., Conen, F., Dobbie, K. E., Massheder, J., Rey, A., 2003. Exchange of greenhouse gases between soil and atmosphere: Interactions of soil physical factors and biological processes. European Journal of Soil Science. 54(4): 779 $-791$.

Soraya, D., Suhara, O., Taofiqurohman, A., 2012. Perubahan garis pantai akibat kerusakan hutan mangrove di 
Kecamatan Blanakan dan Kecamatan Legonkulon, Kabupaten Subang. Perikanan dan Kelautan. 3(4): $355-364$.

Spalding, M. D., Ruffo, S., Lacambra, C., Meliane, I., Hale, L. Z., Shepard, C. C., Beck, M. W., 2014. The role of ecosystems in coastal protection: Adapting to climate change and coastal hazards. Ocean and Coastal Management. 90: 50 - 57.

Supriadi, Romadhon, A., Farid, A., 2015. Struktur komunitas mangrove di Desa Martajasah Kabupaten Bangkalan. Kelautan. 8(1): 44 - 51.

Syahrial., 2018. Keadaan hutan mangrove di Utara Indonesia berdasarkan indikator kualitas lingkungan dan indikator ekologis komunitas. Maspari. 10(1): 89 - 96.

Syahrial, M. 2019. Status biota penempel pasca penanaman mangrove Rhizophora spp. di Kepulauan Seribu: Studi kasus Filum moluska. JFMR-Journal of Fisheries and Marine Research, 3(2), 46-57. https://doi.org/10.21776/ub.jfmr.20 19.003.02.7

[UNEP] United Nations Environment Programme., 2014. The Importance Of Mangroves To People:A Call To Action. van Bochove J, Sullivan E, Nakamura T. (Eds). United Nations Environment Programme World Conservation Monitoring Centre, Cambridge. 128 pp.

Valiela, I., Bowen, J. L., York, J. K., 2001. Mangrove forests: One of the world's threatened major tropical environments. BioScience. 51(10): 807-815.

Van Laake, P. E., Sanchez-Azofeifa, G. A., 2004. Focus on deforestation: Zooming in on hot spots in highly fragmented ecosystems in Costa Rica. Agriculture, Ecosystems and Environment. 102(1): 3 - 15.

Wolanski, E., Spagnol, S., Thomas, S., Moore, K., Alongi, D. M., Trott, L., Davidson, A., 2000. Modelling and visualizing the fate of shrimp pond effluent in a mangrove-fringed tidal creek. Estuarine, Coastal and Shelf
Science. 50(1): 85 - 97.

Woodroffe, C. D., Grindrod, J., 1991. Mangrove biogeography: The role of quaternary environmental and sea-level change. Biogeography. 18(5): $479-492$.

Yang, Q., Tam, N. F. Y., Wong, Y. S., Luan, T. G., Su, W. S., Lan, C. Y., Shin, P. K. S., Cheung, S. G., 2008. Potential use of mangroves as constructed wetland for municipal sewage treatment in Futian, Shenzhen, China. Marine Pollution Bulletin. 57(6-12): 735 - 743. 
